\title{
ARTíCULOS
}

\section{LA VERDAD SOBRE EL CASO BATARRITA. DICTADURA, PROPAGANDA Y MICROHISTORIA EN EL PAÍS VASCO}

\author{
The truth about the Batarrita case. \\ Dictatorship, propaganda and microhistory in the Basque Country
}

Gaizka Fernández Soldevilla

Fundación Centro para la Memoria de las Víctimas del Terrorismo

investigación@centromemorialvt.com

Recibido: 13/02/2017 - Aceptado: 18/10/2017

Cómo citar este artículo/Citation:

Gaizka FERNÁNDEZ SOLDEVILLA (2018), “La verdad sobre el caso Batarrita. Dictadura, propaganda y microhistoria en el País Vasco", Hispania Nova, 16, págs. 26I-292, DOI: https://doi.org/10.20318/hn.2018.4038

Resumen: El 27 de marzo de 196I la Policía acabó con la vida de Javier Batarrita en un control a la entrada de Bilbao. El gobernador civil de Vizcaya informó de que su coche había sido confundido con el de unos "terroristas". En el juico los policías y guardias civiles procesados fueron absueltos. Ahora bien, la versión más extendida es que se trató de una "ejecución extrajudicial" para matar a tres líderes de ETA. La finalidad del presente trabajo es averiguar qué ocurrió realmente aquel día. Además, se pretenden extraer algunas lecciones acerca de la instrumentalización del pasado en el País Vasco.

Palabras clave: Dictadura franquista, Bilbao, Javier Batarrita, ETA, Julen Madariaga.
Copyright: () HISPANIA NOVA es una revista debidamente registrada, con ISSN II38-7319 y Depósito Legal M 9472-1998. Los textos publicados en esta revista están -si no se indica lo contrario- bajo una licencia Reconocimiento-Sin obras derivadas 3.0 España de Creative Commons. Puede copiarlos, distribuirlos y comunicarlos públicamente siempre que cite su autor y la revista y la institución que los publica y no haga con ellos obras derivadas. La licencia completa se puede consultar en: http://creativecommons.org/licenses/by-nd/3.0/es/deed.es

Abstract: On March 27, 196I, the police killed Javier Batarrita in a checkpoint at the entrance to Bilbao. The civil governor of Vizcaya reported that his car had been mistaken for "terrorists". In court, the police and civil guards were absolved. Now, the most widespread version is that it was an "extrajudicial execution" to kill three ETA leaders. The purpose of this paper is to find out what really happened that day. In addition, some conclusions can be drawn on the use of the past in the Basque Country.

Keywords: Franco dictatorship, Bilbao, Javier Batarrita, ETA, Julen Madariaga. 


\section{Introducción ${ }^{1}$}

En marzo de 2014 el diario Gara publicó un reportaje de Iñaki Egaña Sevilla acerca de "la primera víctima del llamado conflicto vasco", supuestamente producida 53 años antes. Siguiendo el texto, el 27 de marzo de 1961 miembros de las FOP (Fuerzas de Orden Público) se apostaron en Bolueta, a la entrada de Bilbao. "Casi a las diez de la noche" pararon un Peugeot 403, abrieron sus puertas y "dispararon contra sus ocupantes". Los agentes abandonaron la escena "sin preocuparse por el estado de las víctimas". Creían haber "ejecutado" a Julen Madariaga, José Mari Benito del Valle y Manu Agirre, dirigentes de ETA, Euskadi Ta Askatasuna (Euskadi y Libertad). Aquellos policías y guardias civiles se habían equivocado: los ocupantes del coche eran "tres jóvenes ajenos a cualquier organización", quienes "habían sido literalmente fusilados", por haberles "creído militantes de ETA". Hubo un muerto, Javier Batarrita Elexpuru, que recibió "49 impactos", y un herido grave, "José A. Ballestero [sic]", quien quedó paralítico. A decir del autor, Julen Madariaga poseía un automóvil "de las mismas características y color que Javier Batarrita", lo que había motivado la confusión. "La pista que al parecer siguió la policía, provenía de una reunión que habían celebrado Benito del Valle y Manu Agirre en Gasteiz con Rubén López de Lakalle y Ángel Aranzabal para formar un grupo de ETA en la capital alavesa". La

\footnotetext{
${ }^{1}$ El autor desea agradecer las útiles sugerencias, correcciones y aportaciones de Abel García Roure, Florencio Domínguez Iribarren, José Luis de la Granja, Raúl López Romo, Jesús Casquete, Lorenzo Castro, Juan Luis Ibarra Robles, Daniel Etxebarria, Manuel Aguilar Gutiérrez, Juan Francisco López Pérez, José Antonio Pérez Pérez, José Francisco Briones Aparicio, María del Carmen Alba, Jacques Pons, Teo Santos, Jesús Rueda, María del Pilar Rodríguez, Antonio Rivera y Gorka Angulo. Este trabajo se enmarca en dos proyectos de investigación subvencionados por la Secretaría de Estado de Investigación, Desarrollo e Innovación: "El terrorismo europeo en los años de plomo: un análisis comparativo", con referencia HAR2015-65048-P, y "Héroes y villanos de la patria. La creación y socialización de arquetipos (anti-)nacionales en la historia contemporánea vasca en perspectiva comparada", con referencia HAR2015-64920-P.
} 
viuda de Batarrita fue "detenida en la comisaría de Indautxu" por llamar "asesinos" a los agentes, quienes solo habían regresado a Bolueta "cuando tuvieron constancia de la "equivocación" para borrar las huellas del crimen". "Diez policías serían juzgados por el Crimen de Bolueta. El resultado fue la absolución”"2.

En el relato faltaba un detalle que el propio Egaña Sevilla había apuntado en una referencia anterior, de 2010: que Batarrita provenía de un entorno similar al de José Antonio Martín-Ballestero, es decir, que ambos pertenecían "a conocidas familias franquistas" 3 . Sin embargo, en el reportaje de 2014 únicamente mencionaba que el segundo era "hijo del exgobernador civil de Orense". De los parientes de Batarrita ya no se decía nada. Se había borrado del texto esa incómoda adscripción políticofamiliar, que resultaba incompatible con el propósito que Egaña Sevilla manifestaba en 2014: elevar a Javier Batarrita a la categoría de "primera víctima del llamado conflicto vasco, en su fase más reciente".

Excepto por tal novedosa reinterpretación de la víctima, Egaña Sevilla estaba repitiendo una narración que primero había aparecido en un boletín de la organización juvenil del PNV, Partido Nacionalista Vasco, y que luego recuperaron y ornamentaron ETA y su entorno. Tras desplazar a la versión oficial de la dictadura, este relato abertzale (patriota) acerca del "suceso de Bolueta" ha logrado convertirse en canónico, no solo en las políticas de memoria de las instituciones, sino también en la esfera académica; e incluso en publicaciones promovidas por la Guardia Civil ${ }^{4}$. Ahora bien, la lectura de los acontecimientos que se hace en pleno siglo XXI es tan inexacta como la que el régimen había realizado a principios de los años sesenta. Ambas interpretaciones mezclan hechos, medias verdades y mentiras. $Y$ es que en lo referente al caso Batarrita la propaganda (primero franquista, luego abertzale) siempre ha prevalecido sobre la historia.

La principal finalidad del presente trabajo es averiguar todo lo posible acerca de qué ocurrió en Bolueta la noche del 27 de marzo de 1961 y qué consecuencias tuvo.

\footnotetext{
${ }^{2}$ Iñaki EGAÑA SEVILLA, “Javier Batarrita, la primera víctima”, Gara, 27 de marzo de 2014.

${ }^{3}$ Iñaki EGAÑA SEVILLA, “Memoricidio”, Gara, 4 de diciembre de 2010.

${ }^{4}$ Manuel SÁNCHEZ y Manuela SIMÓN, Historia de un desafío. Cinco décadas de lucha sin cuartel de la Guardia Civil contra ETA, Barcelona, Península, 2017, p. 49. Lorenzo SILVA, Manuel SÁNCHEZ y Gonzalo ARALUCE, Sangre, sudor y paz. La Guardia Civil contra ETA, Barcelona, Península, pp. 33-34.
} 
Se trata de ofrecer un relato plausible, veraz y riguroso, elaborado por medio de la metodología del historiador y el examen exhaustivo de las fuentes disponibles (bastantes de ellas inéditas): bibliografía, prensa de la época, publicaciones nacionalistas, documentación gubernativa y policial, sumarios y sentencias judiciales.

A decir de Tony Judt, además de "establecer que cierto hecho ocurrió", de explicarlo, los historiadores tienen "una responsabilidad más: una obligación respecto a los debates contemporáneos"5. Y uno de los debates más candentes en el País Vasco y Navarra es el que gira en torno al choque entre distintos relatos sobre la violencia política. Así, aquí se apunta a un segundo objetivo: aprovechar el estudio de un caso concreto para extraer algunas lecciones acerca de la manipulación e instrumentalización del pasado, o sea, ir de un análisis particular a otro general sobre los (malos) usos de la historia.

\section{2. ¿"Trágico error" o "emboscada sangrienta"? Dos relatos divergentes (196I)}

La primera pista de que el lunes 27 de marzo de 1961 había ocurrido una tragedia en Bilbao apareció en los medios de comunicación locales al día siguiente. En los diarios La Gaceta del Norte y El Correo Español. El Pueblo Vasco se insertó la esquela de Javier Batarrita Elexpuru, en la que se informaba de que había fallecido a los 33 años de edad y de que su funeral de cuerpo presente se iba a oficiar a las seis de la tarde en la parroquia de San Francisco de Asís (Bilbao). La nota se publicó en la página 4 de ambos periódicos ${ }^{6}$.

La agencia Cifra (es decir, EFE) transmitió la versión oficial de lo sucedido, que la prensa de toda España recogió el miércoles 29: en $A B C$ (Madrid) la noticia se titulaba "Trágico error"; en La Vanguardia Española (Barcelona) "Desgraciada coincidencia en las características de un automóvil"; en La Voz de España (San Sebastián) "La guardia civil dispara erróneamente sobre un coche que se dirigía hacia Bilbao"; en El Diario Vasco (San Sebastián) "Desgraciado suceso en Bilbao, a

\footnotetext{
${ }^{5}$ Tony JUDT y Timothy SNYDER, Pensar el siglo XX, Madrid, Taurus, 2012, pp. 257-258.

${ }^{6}$ El Correo Español y La Gaceta del Norte, 28 de marzo de 1961.
} 
consecuencia del cual resultó una persona muerta y otra gravemente herida"; en El Correo Español (Bilbao) "El lamentable suceso del lunes en Bolueta"; y en La Gaceta del Norte (Bilbao) "Un lamentable error de consecuencias trágicas, en Bolueta"”.

En la portada de los dos diarios bilbaínos se publicó una insólita nota de Antonio Ibáñez Freire, un militar vitoriano, de tendencia falangista, que dos semanas antes había tomado posesión del cargo de gobernador civil de Vizcaya (1961-1963) ${ }^{8}$, tras ocupar el mismo puesto en Santander (1960-1961) y el de procurador en las Cortes franquistas (1958-1971). De acuerdo con sus explicaciones, el día 27 "patrullas de servicio volante de Orden Público" se habían apostado en Bolueta "como consecuencia de referencias urgentes recibidas de Vitoria" acerca de la salida de un coche de determinadas "características exteriores" y "en el que se creía viajaban tres elementos sospechosos de actividades terroristas, portadores de armas", a los que se planeaba detener. No obstante, "y sin que todavía se hayan podido determinar las causas, se originaron varios disparos, a consecuencia de los cuales resultó uno de los ocupantes muerto, otro herido e ileso el tercero": eran, respectivamente, el comercial Javier Batarrita Elexpuru, el abogado José Antonio Martín-Ballestero y Martínez de Velasco, de Calatayud, y el jefe administrativo Fernando Larizgoitia Mimenza, natural de Bilbao, al igual que el primero. Al tener noticia del "desgraciado resultado" del servicio, el teniente coronel de la Guardia Civil y el jefe superior de Policía de Vizcaya se habían trasladado inmediatamente al lugar "para investigar lo ocurrido, dando cuenta seguidamente a este Gobierno". Ibáñez Freire se había puesto en contacto con el gobernador militar para que nombrase "un juez especial" que esclareciese "los hechos ocurridos y determine las responsabilidades a que hubiere lugar". Para concluir, manifestaba "su pesar a las familias de las víctimas" y reiteraba "su confianza en que los hechos y las pertinentes responsabilidades quedarán determinadas con la máxima diligencia" ${ }^{\prime}$.

Los dos periódicos añadieron junto a la nota sendos editoriales en los que respaldaban a Ibáñez Freire y daban muestras de su fe en la justicia franquista. Ahora

\footnotetext{
${ }^{7}$ ABC, La Vanguardia Española, La Voz de España, El Diario Vasco, El Correo Español y La Gaceta del Norte, 29 de marzo de 1961.

${ }^{8}$ La Gaceta del Norte, 14 de marzo de 1961.

${ }^{9}$ El Correo Español y La Gaceta del Norte, 29 de marzo de 1961.
} 
bien, también aportaban nuevos datos y alguna hipótesis. El Correo Español, que asumía que "es humano errar", indicó que las FOP "ni siquiera dispusieron de tiempo para someter a la Superioridad un plan de acción" y que en Bolueta los agentes "alarmados seguramente -según una versión plausible de los hechos- por un disparo suelto que se supuso equivocadamente que provenía del coche que se trataba de detener, efectuaron varios disparos". Los gobernadores civil y militar habían acudido al Hospital del Generalísimo (Basurto) "para interesarse por el estado del herido y expresar su pésame a los familiares del muerto". El diario dedicaba una mención especial a Javier Batarrita, representante de la marca de motocicletas Lube, cuya fábrica se situaba en Baracaldo. Era "muy conocido y querido en los medios de la Villa por sus actividades comerciales y deportivas": aficionado tanto al motorismo como al ciclismo, colaboraba activamente con la Vuelta Ciclista a España, organizada por El Correo. Su muerte era, por consiguiente, "doblemente dolorosa para nosotros"10.

La nota de la redacción de La Gaceta del Norte se unía al "profundo sentimiento" por el fallecimiento de un "convecino nuestro, que gozaba de gran popularidad y simpatía en nuestra Villa". Tras asumir que "hechos como éste, con todas sus trágicas consecuencias, pueden ocurrir y ocurren, desgraciadamente, en todas partes", advertía que no se podía "disculpar la imprudencia temeraria que, con las circunstancias agravantes que concurren en el hecho, será aquilatada por los Tribunales competentes". Según el periódico, al ser "imprecisamente conocido anteayer en la Villa" el suceso, había producido "una honda conmoción en la opinión pública". Añadía, además, que Ibáñez Freire había permanecido en el hospital "toda la noche de anteayer y el día de ayer". El día 28 convocó a los medios en su despacho para transmitirles "su dolorosa impresión"11. La siguiente referencia en la prensa fue una nota necrológica de la familia de Javier Batarrita agradeciendo los testimonios de pésame y comunicando la hora y el lugar de las misas de salida ${ }^{12}$.

Poco después las publicaciones nacionalistas vascas que se editaban en Francia y Latinoamérica transmitieron una versión de los hechos que, en lo esencial,

\footnotetext{
${ }^{10}$ El Correo Español, 29 de marzo de 1961.

${ }^{11}$ La Gaceta del Norte, 29 de marzo de 1961.

${ }^{12}$ La Gaceta del Norte, 2 de abril de 1961.
} 
no difería demasiado de la que habían dado El Correo Español y La Gaceta del Norte. La primera en hacerse eco fue el boletín OPE, Oficina de Prensa de Euzkadi, órgano oficial del Gobierno vasco en el exilio. El 4 de abril de 1961, bajo el titular "Emboscada sangrienta en Bilbao", repitió la explicación del gobernador civil. "Se habla de un error", señalaba OPE, "pero es creencia general que, si las víctimas del error hubieran sido personas de antecedentes antifranquistas, es seguro que no hubiera habido ni responsabilidades, ni juez especial ni referencia alguna de este asunto en la prensa". Al día siguiente OPE denunció la actitud servil de los diarios bilbaínos para con las autoridades. Asimismo, relacionándolo con el control policial de Bolueta, el boletín comunicó que "en las últimas semanas" las FOP habían buscado "depósitos clandestinos de armas" en cementerios próximos a San Sebastián ${ }^{13}$. Otros medios reprodujeron el contenido de OPE: Tierra Vasca, editada en Buenos Aires por ANV, Acción Nacionalista Vasca; España Libre, órgano en París de la CNT, Confederación Nacional del Trabajo; y Euzko Deya, publicación del Gobierno vasco en México. En opinión de los redactores de esta última, lo sucedido en Bilbao era "una muestra de los procedimientos usados por la fuerza pública cuando cree que puede emplearlos impunemente por tratarse de "enemigos del régimen". Sin embargo, las víctimas habían resultado ser "elementos afectos al régimen"14.

Jon Juaristi recuerda en sus memorias que muchos nacionalistas vascos consideraron que "el incidente" de Bolueta no era más que "un asesinato premeditado". "Más aún, se entendió como una agresión del franquismo contra los vascos"15. La pieza clave para que cristalizara y se expandiera dicha interpretación fue Gudari, el órgano de expresión de EGI, Euzko Gaztedi (Juventud Vasca) del Interior, la organización juvenil del PNV. Su $n^{\circ} 2$ (extra) estuvo casi íntegramente dedicado al asunto, bajo el epígrafe de "Batarrita: su nombre acusa al Franquismo". Se sustentaba en el testimonio de varios miembros de EGI que se habían desplazado a Bolueta al percibir un inusitado despliegue de "30 a 35 policías con metralletas". La cifra era la primera de una serie de datos novedosos que aportaba Gudari. Otros eran la hora, "las 9:48 exactamente", y el modelo del automóvil de Batarrita: un "Peugeot 403,

\footnotetext{
${ }^{13}$ Oficina de Prensa de Euzkadi, 4 y 5 de abril de 1961.

14 Tierra Vasca, abril de 1961. España Libre, 23 de abril de 1961. Euzko Deya, mayo de 1961.

15 Jon JUARISTI, Cambio de destino, Barcelona, Seix Barral, 2006, p. 98.
} 
descapotable, color claro". Según el informe, "un guardia civil detuvo el coche y apuntando al conductor con su metralleta le ordenó que estacionara en la esquina". Este obedeció, "detuvo el automóvil y abrió la portezuela para averiguar qué pasaba. Sonó un disparo y luego se sintió el traqueteo de metralletas mezclado con disparos de fusil y pistola. Los disparos continuaron con furor unos segundos". El muerto era "hijo de un exconcejal nacionalista vasco". EGI "pudo averiguar que Batarrita tenía nueve balazos en la cabeza y más de cuarenta en el cuerpo". El herido, Martín-Ballestero, "hijo de un coronel del ejército, que actualmente es gobernador de La Coruña", fue trasladado "urgente (y secretamente) a un hospital particular". Por último, "Larizgoitia fue llevado al Gobierno Civil". Ulteriormente, las FOP se habían dedicado a "borrar los vestigios del hecho" y amenazar a "los atemorizados empleados" de la gasolinera. Según Gudari, al día siguiente "estalló un enorme escándalo en Bilbao". El boletín recogía diferentes rumores, como que "las fuerzas de policía se hallaban al acecho de tres terroristas que llegaban cargados de armas desde Vitoria" o que la muerte de Batarrita se podía haber debido a una posible venganza. También había espacio para la mordacidad: "a los esbirros que realizaron la masacre se les enviará a Cuenca y serán ascendidos" ${ }^{16}$.

Las fuentes utilizadas hasta ahora, por sí mismas, no nos permiten resolver el rompecabezas. No solo no concuerdan entre sí, sino que su fiabilidad, en el mejor de los casos, es reducida. Lo es la de los periódicos publicados en España, porque carecían de libertad de prensa: estaban atenazados por la censura previa y el control gubernamental, lo que los convertía en voceros oficiosos del régimen. Se comprende así que a principios de los años sesenta un conserje le dijera al hispanista Gabriel Jackson que "la prensa era tan aburrida que la gente se empezaba a olvidar de leer y escribir en castellano" ${ }^{17}$. Ahora bien, el contenido de las publicaciones editadas en el exilio tampoco es del todo fidedigno, ya que, en su mayoría, se trataba de propaganda militante, con difícil acceso a testimonios de primera mano, por lo que a menudo reproducía los textos de los diarios publicados en el interior de España, eventualmente adornados con elucubraciones de cosecha propia. Sin minusvalorar algunas de las pistas que nos transmite, es necesario realizar una lectura cauta y crítica de la

\footnotetext{
${ }^{16}$ Gudari, abril de 1961.

${ }^{17}$ Gabriel JACKSON, Memoria de un historiador, Barcelona, Crítica, 2009, p. 95.
} 
hemeroteca. De igual manera hay que juzgar las dos versiones divergentes que se habían dibujado, la franquista y la abertzale, entre las que se detectan demasiadas discrepancias. ¿Se había tratado de un "trágico error" o de una premeditada "emboscada sangrienta"? ¿Batarrita había recibido varios disparos o más de cuarenta y nueve? ¿Las FOP habían abandonado el lugar de los hechos desentendiéndose de las víctimas o las habían llevado al hospital? No obstante, pese a sus discrepancias, lo cierto es que ambas interpretaciones coinciden en un punto fundamental: ninguna de ellas relacionaba a los miembros de ETA con los supuestos "terroristas" a los que buscaban las FOP. Ni siquiera se mencionaba a esta organización.

\section{El proceso. FOP contra FOP}

Teniendo en cuenta la caída en desgracia de otros gobernadores civiles tras contingencias similares, no es descartable que el espinoso caso Batarrita pudiese haber llegado a sepultar la incipiente carrera política de Ibáñez Freire, cuya ambición queda patente al reparar en los altos cargos que alcanzó durante sus últimos años en activo: director general de la Guardia Civil (1976-1978) y ministro del Interior (19791980). No era la única razón que el gobernador tenía para intentar neutralizar el problema. No hay que obviar ni las conexiones familiares de Martín-Ballestero, de las que se hablará más adelante, ni la popularidad de Batarrita en Bilbao. En ese sentido, a decir de Joseba Zulaika, el teniente alcalde de la ciudad, Javier de Ybarra (asesinado por ETA en 1977), "estaba indignado con la policía"18. En tal coyuntura se situaba el gobernador civil de Vizcaya, que reaccionó de forma rápida y audaz. Lo hizo en el plano mediático, pero también en el político y judicial. Por ejemplo, en la Memoria del Gobierno Civil de Vizcaya de 1961, Ibáñez Freire informó a sus superiores de que la provincia gozaba de un clima de normalidad. No mencionaba el caso Batarrita, pese a que había trascendido a la prensa nacional. $Y$ es que, para entonces, el potencial escándalo ya había sido desactivado. Dos años después Franco nombró a Ibáñez Freire gobernador civil de Barcelona (1963-1966), lo que suponía un ascenso ${ }^{19}$.

\footnotetext{
${ }^{18}$ Joseba ZULAIKA, Vieja luna de Bilbao. Crónicas de mi generación, San Sebastián, Nerea, 2014, pp. 46-47.

19 "Memoria del Gobierno Civil de Vizcaya de 1961", 1962. AGCV (Archivo del Gobierno Civil de
} 
Volviendo atrás, el 28 de marzo se inició la primera fase de la investigación, que conocemos detalladamente gracias al sumario. También a las memorias (manifiestamente hostiles a la Guardia Civil) del comisario José Sainz González, quien culminaría su carrera como director general de la Policía (1979-1980), pero que en aquel momento formaba parte de la sección bilbaína de la Brigada de Investigación Social, popularmente conocida como Político-Social. Sainz sostenía, y la documentación judicial lo avala, que la Benemérita pretendió "apartarse de lo sucedido y cargar toda la responsabilidad a la Policía". Un guardia civil, el que paró el coche, armado con un subfusil ametrallador, juró no haber disparado y el otro dijo que solo había realizado un tiro con su máuser. Así empezó el conflicto entre ambos cuerpos: en las diligencias que instruyeron los guardias civiles se culpaba a los policías y en las de los policías a los guardias civiles. En opinión de Sainz, el gobernador civil "se inhibió de tomar partido en el asunto": dejó hacer al juez militar en funciones, quien, al igual que los médicos militares encargados de la autopsia, deseaba utilizar a los agentes de Policía como cabezas de turco. El sumario revela que, además, los maestros armeros del cuartel de Garellano no identificaron balas ni casquillos del subfusil del guardia civil, declarando que este no había sido disparado (cuando exámenes posteriores demostrarían que esas dos negaciones eran falsas, es decir, que el miembro de la Benemérita había mentido). Por añadidura, el juez militar que fue enviado por la Capitanía General de Burgos para hacerse cargo del caso, se quejaba Sainz, "nos trató con el mayor despotismo y falta de consideración", "peor que si fuéramos delincuentes". De cualquier modo, en total se procesó a cuatro inspectores y dos subinspectores de la Brigada de Investigación Social, dos policías armados y la pareja de la Guardia Civil ${ }^{20}$.

La disputa entre los cuerpos también quedó reflejada en el $n^{\circ} 3$ de Gudari, editado en junio de 1961. "La Guardia Civil mostró sus armas para demostrar que sus agentes no dispararon. Los policías secretos quisieron hacer lo mismo, pero al parecer llevaron a la inspección otras armas". Según el texto de EGI, "parece que,

Vizcaya). Sobre Ibáñez Freire véanse El Mundo, 11 de mayo de 2003, y Martí MARÍN CORBERA, "Una década de estabilidad relativa (1960-1969)", Javier TÉBAR HURTADO, Gobernadores. Barcelona en la España franquista (1939-1977), Granada, Comares, 2015, pp. 185-262.

20 Juzgado no 3 de la Audiencia de Bilbao, "Sumario n 295", 1961-1963. Audiencia Provincial 1/3. Archivo Histórico Provincial de Vizcaya (AHPV). José SAINZ GONZÁLEZ, Testimonios de un policía español, autoedición, 1993, pp. 125-126. 
definitivamente, fue la policía secreta la que asesinó a Batarrita e hirió de gravedad a Ballestero [sic]"21.

En junio de 1961 la jurisdicción militar se inhibió en favor de la ordinaria, la cual, a decir de Sainz González, "hubo de deshacer los entuertos de las estrellas [los oficiales del Ejército] y aquilatar al máximo en los exámenes periciales" ${ }^{\text {"2 }}$. La fase oral del juicio se inició el 21 de marzo de 1963. Al día siguiente apareció en El Correo Español la primera de las crónicas en las que se dio cuenta del proceso, que había generado cierta expectación. "La sala de la Sección Segunda rebosaba de público". Podemos entresacar de estos reportajes una serie de datos. El primero, que "momentos antes del juicio" se había retirado "la acusación privada", es decir, los parientes de las víctimas, "quienes en virtud de indemnización recibida- superior a los cuatro millones de pesetas [769.000 euros actuales] por cada familia, según tenemos entendido- han desistido de todas las acciones e indemnizaciones que les pudieran corresponder". Así pues, la acusación se redujo al fiscal jefe de la Audiencia de Bilbao. Debido a su responsabilidad civil subsidiaria, el Estado estuvo representado por un abogado del Estado. En segundo término, "las declaraciones de los miembros de los diferentes cuerpos discrepaban radicalmente, al igual que luego discreparian los testimonios de los testigos presentados por una y otra defensa". Mientras los guardias civiles alegaban no haber disparado, los policías afirmaban que lo habían hecho después de escuchar uno o varios tiros, que creían provenir del automóvil de Batarrita. Tercero, los médicos forenses que habían realizado la autopsia expusieron que el cuerpo de la víctima "había sido penetrado por numerosos proyectiles". Arrojó más luz, en cuarto lugar, el informe verbal de nueve peritos armeros, especialmente el de José Junquera Quintía, director del Banco Nacional de Pruebas de Armamento de Eibar, quien verificó, entre otras cosas, que los proyectiles encontrados eran de armas cortas, como las que usaban los policías, pero también del máuser y el subfusil ametrallador de los que disponían los guardias civiles. Por último, fueron llamados cuarenta y cinco testigos, aunque "algunos no comparecieron y otros fueron renunciados". Entre los que sí declararon se encontraban Fernando Larizgoitia Mimenza, un número indeterminado de policías que habían estado presentes en Bolueta pero sin armas, sus superiores,

\footnotetext{
${ }^{21}$ Gudari, no 3, junio de 1961.

22 José SAINZ GONZÁLEZ, Testimonios..., op. cit., p. 126.
} 
dos empleados de la gasolinera, algunos camioneros, etc. "Aunque había sido convocado, no pudo personarse y envió un telegrama desde Madrid, donde actualmente reside, el señor Martín Ballestero, hoy paralítico, a consecuencias de las graves lesiones entonces sufridas". A decir del reportero, "hubo testimonios para todos los gustos"23. Ese mismo día El Diario Vasco informó del juicio, aunque de forma más breve ${ }^{24}$. Llamativamente ambos periódicos contenían el mismo error: fechaban el "suceso de Bolueta" el 26 de marzo de 1960. Aquel desliz nos sirve para detectar a quienes, posteriormente, reprodujeron el contenido de aquellos dos diarios sin contrastarlo: a corto plazo, Oficina de Prensa de Euzkadi y Gudari; a largo, libros y artículos de diversa índole ${ }^{25}$.

La siguiente crónica anunció que el fiscal pedía dos años de prisión para cada uno de los diez procesados mientras que los abogados defensores solicitaban su libre absolución. El juicio estaba visto para sentencia, la cual, en palabras del redactor, "no dudamos será benigna, una vez oídos los informes de los letrados e, incluso, el del fiscal jefe de nuestra Audiencia, señor Aya, en las cuales quedaron bien patente las especiales circunstancias fatales que motivaron el lamentable suceso". A su modo de ver, la muerte de Batarrita había conmovido "profundamente la conciencia de todos, incluido la de los propios responsables y, a la vez, víctimas del hecho. En fin, nadie está libre de incurrir en error en algún momento de su vida" ${ }^{26}$.

No obstante, las pruebas habían desmontado el testimonio de los guardias civiles y la jurisdicción ordinaria se presuponía menos comprensiva con ellos que la militar. Además, aunque esto afectaba a todos los encausados, había precedentes

\footnotetext{
${ }^{23}$ El Correo Español, 22 de marzo de 1963. Respecto a la indemnización, el periodista reconoció ulteriormente que se trataba de una "cuantía que desconocemos" (El Correo Español, 27 de marzo de 1963). El hijo de Javier Batarrita ha negado que su madre hubiese recibido algún tipo de ayuda (Deia, 6 de abril de 2014), pero la causa judicial confirma que los allegados de las dos víctimas habían sido "debidamente indemnizados por el Estado", aunque desconocemos la cantidad exacta. El fiscal había solicitado 508.025 pesetas [97.000 euros actuales] para la familia de Batarrita y 800.000 [153.000 euros] para la de Martín-Ballesteros, de las que había de hacerse cargo el Estado, dada la "insolvencia" de los procesados. La acusación particular había pedido 6.531 .000 pesetas [1.255.000 euros] para la familia de Batarrita y 1.000 .000 [192.000 euros] para la de Martín-Ballesteros. Nota bene: he actualizado todas las cifras, en función de la evolución del IPC general, a euros de diciembre de 2016 (http://www.ine.es/calcula/)

${ }^{24}$ El Diario Vasco, 22 de marzo de 1963.

${ }^{25}$ OPE, 29 de marzo de 1963, y 2 de abril de 1963. Gudari, n 18, 1963.

${ }^{26}$ El Correo Español, 24 de marzo de 1963. La Gaceta del Norte, 24 de marzo de 1963.
} 
cercanos de agentes encarcelados por delitos de sangre. Por ejemplo, apenas unos días después de la muerte de Batarrita, el Tribunal Supremo había confirmado una sentencia dictada por la Audiencia de Bilbao por la que se condenaba a un guardia municipal de Valmaseda a ocho años de prisión mayor por homicidio "con la atenuante de obrar en cumplimiento de un deber y en el ejercicio legítimo de su cargo, así como a pagar doscientas mil pesetas [44.600 euros actuales] de indemnización a los herederos de la víctima". El policía medió en una disputa y, como uno de los contendientes se había resistido tenazmente a la detención, le disparó con su arma reglamentaria, hiriéndole de muerte ${ }^{27}$.

La última noticia acerca del proceso salió en la edición del 27 de marzo de 1963 de El Correo Español y El Diario Vasco, así como al día siguiente en La Gaceta del Norte, que le había prestado menos atención. Los jueces consideraron que las víctimas habían tenido una actitud "obediente y respetuosa para los agentes de la Autoridad". En cambio, uno de los miembros de las FOP había cometido una "imprudencia en grado temerario" al pegar un tiro con su arma sin motivo previo, lo "que fue la causa inicial del resultado lesivo". Hizo "que los demás procesados creyeran erróneamente que el disparo había sido hecho por los ocupantes del coche, y que estos eran los terroristas que tenían que detener", así que se defendieron del supuesto ataque con sus armas. Tal error, "a juicio de la Sala", no fue "imputable a descuido o negligencia”. No obstante, pese a la investigación, no se había podido precisar quién de los diez acusados había hecho fuego en primer lugar, es decir, quién era el responsable de la tragedia. En consecuencia, la Audiencia de Bilbao absolvió a todos los agentes ${ }^{28}$.

El veredicto no satisfizo a OPE, que, tras recordar la cifra de cuatro millones de pesetas que en teoría habían recibido las familias de Batarrita y Martín-Ballestero, ironizaba: "esperamos que pronto se pronuncie el ascenso de estos diez exprocesados". Gudari era implacable: "Jueces a sueldo absuelven a asesinos pagados". Los policías y los guardias civiles habían matado "a mansalva a dos honestos ciudadanos". El dictamen de la Audiencia de Bilbao constituía "un

\footnotetext{
${ }^{27}$ OPE, 6 de abril de 1961.

${ }^{28}$ El Correo Español y El Diario Vasco, 27 de marzo de 1963. La Gaceta del Norte, 28 de marzo de 1963.
} 
monumento al cinismo". En opinión de los jóvenes de EGI, "así cuida el franquismo a sus esbirros. Así absuelve a sus asesinos asalariados" ${ }^{29}$.

\section{Un relato razonablemente verosímil (pero con cabos}

\section{sueltos)}

El Archivo Histórico Provincial de Vizcaya custodia la causa judicial de $1963^{30}$. El sumario y el rollo conforman un documento valiosísimo, de casi mil doscientas páginas, que reúne las diligencias, las declaraciones, los certificados, los careos, los telefonemas, los informes periciales, las fotografías, los croquis, las conclusiones de los abogados y el fiscal, el acta, la sentencia, etc. Al contrastar esta información con la que nos transmiten las otras fuentes logramos un relato verosímil de lo que sucedió el 27 de marzo de 1961.

Los diez miembros de las FOP habían sido acusados del "delito de imprudencia temeraria con resultado de homicidio, lesiones graves y daños". Todos ellos eran "de conducta buena, con instrucción, sin antecedentes penales", y se declararon "insolventes", ya que se les había solicitado un total de 800.000 pesetas [153.000 euros actuales] como fianza. En aquel momento se encontraban en "libertad provisional". Fueron defendidos por tres abogados, uno por cuerpo policial. Repasemos los hechos que, prudentemente, podemos considerar probados.

En marzo de 1961 habían llegado "confidencias y noticias a los servicios de información" acerca de "planes que los elementos extremistas se proponían desarrollar para llevar a cabo en nuestra Patria, mediante atentados terroristas, algún golpe de efecto, parecido a los que habían tenido lugar espectacularmente en otros países". ¿A qué misterioso "golpe de efecto" se hacía referencia? Teniendo en cuenta las fechas, la opción más probable es que al secuestro del trasatlántico portugués Santa María por un comando del DRIL, Directorio Revolucionario Ibérico de Liberación, en enero de

\footnotetext{
${ }^{29}$ OPE, 2 de abril de 1963. Gudari, $\mathrm{n}^{\circ}$ 18, 1963.

${ }^{30}$ Juzgado $n^{\circ} 3$ de la Audiencia de Bilbao, "Sumario $n^{\circ} 295$ ", op. cit. Si no se indica lo contrario, toda la información del presente apartado proviene de esta fuente. Una copia de la parte del sumario instruido por la jurisdicción militar se custodia en el Juzgado Togado Militar Territorial $n^{\circ} 43$ (Burgos). Una copia de la sentencia se encuentra en el Archivo del Tribunal Superior de Justicia del País Vasco.
} 
1961, acción que copó las portadas de los periódicos durante días. Creado en 1959, el DRIL era un efímero colectivo hispanoluso, antifranquista y antisalazarista, que en febrero y junio de 1960 colocó una serie bombas en España. Una de ellas había estallado en la estación de tren de Amara (San Sebastián) el 27 de junio, acabando con la vida de la niña Begoña Urroz lbarrola. Otra había hecho explosión en la parada de Achuri (Bilbao) dos días después ${ }^{31}$. No podemos descartar que la alarma policial respondiese al atentado que el 21 de febrero había sufrido el consulado español de Ginebra, atribuido al movimiento libertario ${ }^{32}$. Una explicación alternativa apunta a los últimos coletazos del maquis. Basten como muestra dos botones. Por un lado, la noche del 3 al 4 de enero de 1960 en la provincia de Gerona un teniente de la Guardia Civil fue abatido por el guerrillero anarquista Francisco Sabaté Llopart (Quico), a quien al día siguiente mató un somaten. Por otro, el 9 de agosto de 1961, siguiendo órdenes de Valentín González González (El Campesino), un grupo de maquis intentó sabotear la central eléctrica del pantano de Irabia (Orbaiceta, Navarra), pero se topó con una pareja de la Benemérita. En el tiroteo murió un guardia civil y resultó herido su compañero. Tanto los guerrilleros de Quico como los de El Campesino procedían de Francia $^{33}$. Tampoco hay que olvidar el contexto internacional: la convulsa etapa que estaba atravesando el Tercer Mundo, inmerso en la encrucijada de la descolonización, la Guerra Fría y las contiendas civiles. Verbigracia, la violencia que estaba asolando Argelia (1954-1962). Por último, hay que tener en cuenta que, en palabras de José Sainz, "de cuantas actividades subversivas se detectaban en aquellos tiempos (...) las que más atención policial merecían eran las del Partido Comunista" y sus satélites. Se trataba de las "más perfeccionadas en esta clase de trabajo, y, por ello, también más difíciles de descubrir por nuestra parte". Así pues, la Policía dedicaba a combatir el comunismo "la más intensa labor investigadora" ${ }^{34}$.

\footnotetext{
${ }^{31}$ La Vanguardia Española, 28 de junio de 1960. El Diario Vasco, 1 de julio de 1960, y 10 de febrero de 1961. La Gaceta del Norte, del 25 de enero al 5 de febrero de 1961. Lorenzo CASTRO, "Retablo de conspiradores. El exilio republicano y la tentación de la violencia (1958-1964)", trabajo inédito.

${ }^{32} A B C, 22$ de febrero de 1961. Dos años antes había sido atacado el consulado de Génova (Alderdi, mayo de 1959).

${ }^{33} A B C, 6$ de enero de 1960, 15 y 24 de agosto de 1961. Diario de Navarra, 11 y 29 de agosto de 1961, y 7 de agosto de 2011. Zutik (Caracas), n 14, 1961.

34 José SAINZ GONZÁLEZ, Testimonios..., op. cit., p. 127.
} 
El 26 de marzo de 1961, dentro del contexto de aquella "situación de alarma", se presentó en la Comandancia de Vitoria un contratista de obras que estaba pasando por apuros económicos, V.G.A., que quería realizar una denuncia: a orillas del río Zadorra había escuchado la conversación de unas once personas que planeaban atentados contra centros oficiales de distintas provincias a modo de distracción antes de "atacar Madrid". Sus objetivos eran el Palacio de El Pardo, el Ministerio del Ejército y el de Gobernación. Los agentes no concedieron "mucho crédito" al testigo, lo que ratifica José Sainz, quien fue enviado a Vitoria para interrogarlo. V.G.A. se refería a un "grupo armado (...) procedente de Francia", que había llegado a la ciudad en dos coches, uno de ellos Peugeot de matrícula francesa ${ }^{35}$.

Al día siguiente, el 27, la Comandancia de Vitoria recibió la llamada telefónica del guarda jurado de la fábrica Inauto, G.P.C., exguardia civil. Comunicó que a las 9:00 había visto llegar "un automóvil gris claro, marca Peugeot, matrícula M-94.430". Las fotografías adjuntas al sumario revelan que se trataba de un modelo 203 y no de un 403, como había apuntado Gudari. Las memorias de Sainz confirman que la matrícula era española, no francesa, aunque "los colores" y marca coincidían con el coche descrito por el testigo precedente ${ }^{36}$. Del vehículo se habían apeado tres hombres, a los que pasó a recoger un cuarto en un Seat, camino de Vitoria. Al estar aquel lugar "muy próximo" al señalado en la anterior denuncia, se envió a una pareja de la Benemérita, pero el automóvil ya no estaba. El guarda jurado les informó de que a las 19:15 los sospechosos habían trasladado "varios paquetes" al Peugeot, saliendo "por la carretera de Bilbao" mientras que el Seat regresó a Vitoria. En realidad, Batarrita, Martín-Ballestero y Larizgoitia habían ido a la ciudad, donde un abogado les recogió en su Seat, a reclamar una deuda al dueño de un garaje. Los misteriosos "paquetes" no eran más que dos cajas de bombones, una cartera de plástico y un sobre tamaño folio con documentos. Por descontado, el Peugeot matrícula M-94.430 no pertenecía a ningún terrorista, sino a Javier Batarrita.

Eran las 20:00 cuando el jefe superior de Policía de Vizcaya, que se había desplazado a Vitoria, "ordenó cursar con toda urgencia avisos a las provincias

\footnotetext{
${ }^{35}$ Ibídem, pp. 122-123.

${ }^{36}$ Ibídem, p. 124.
} 
limítrofes para localizar y detener el vehículo, identificándose a sus ocupantes, y revisándolo para comprobar si transportaba armas o explosivos". A su vez, el teniente coronel de la Guardia Civil llamó a las comandancias de Llodio y Bilbao. No está claro si indicaron que los ocupantes del coche podían ir armados o dieron por hecho que lo estaban: la documentación y los testimonios son contradictorios en este punto ${ }^{37}$.

Catorce miembros de la Brigada Político-Social y dos de la Policía Armada se desplazaron en coche patrulla y taxis a Bolueta, que era considerado el sitio más adecuado para montar un control. Los funcionarios se dieron a conocer a la pareja de la Benemérita que "se hallaba de servicio en dicho lugar". Entonces, entre las 20:20 y 20:30, el guardia civil I.G.M. recibió una llamada desde la Comandancia de Bilbao. Según él, sus superiores le informaron de "que se trataba de saboteadores y llevaban armas". Sin embargo, su compañero no corroboró su testimonio.

De cualquier modo, según la sentencia, todos los agentes tenían "la convicción de que se trataba de una intervención muy importante y muy peligrosa, y temían que, al detener el coche, los ocupantes, a los que suponían elementos extremistas, armados y decididos a todo, hicieran frente a la fuerza pública utilizando armas de fuego". No hubo tiempo para "organizar el servicio". En palabras de José Sainz, "se colocó cada [policía] donde le pareció sin otras armas que no fuera su pistola de $9 \mathrm{~mm}$ corto reglamentaria y sin ningún responsable que coordinara el servicio". Los guardias civiles avanzaron unos metros, sin hacer el "menor caso" a los integrantes del otro cuerpo. Sainz sugiere que tal vez habían recibido la orden de "adelantarse en el servicio a todo trance" ${ }^{38}$.

Entre las 20:30 y 20:45 apareció el Peugeot de Javier Batarrita y alguien gritó “¡Ese es!”. Lo detuvo I.G.M., quien preguntó por su procedencia a Martín-Ballestero, el copiloto. La respuesta fue: "De Vitoria, ¿qué pasa?" Al intentar bajar la ventanilla "con objeto de facilitar la conversación", Martín-Ballestero se agachó ligeramente mientras que Batarrita "abría la puerta izquierda para salir y aclarar mejor los detalles". El guardia civil, creyendo que era el "comienzo de una agresión inminente, retrocedió precipitadamente unos pasos hacia la parte opuesta a la estación de servicio" y apuntó

\footnotetext{
${ }^{37}$ Ibídem, p. 124.

${ }^{38}$ Ibídem, p. 124.
} 
al automóvil con su subfusil ametrallador. "En este momento sonó un disparo que no se puede afirmar categóricamente de donde partió ni quien de los procesados le hiciera", sostiene el veredicto. No obstante, tanto Sainz como bastantes de los policías sospechaban que lo había realizado I.G.M. (o incluso su compañero) ${ }^{39}$. Hay que recordar que el informe pericial demostró que este guardia civil había mentido al declarar no haber hecho fuego. Sea como fuere, creyendo que los sospechosos les atacaban, todos menos uno de los miembros de las FOP procesados habían disparado: I.G.M. con su subfusil ametrallador, el otro guardia civil con su máuser, los policías armados con sus carabinas y los funcionados de la Brigada Político-Social con sus pistolas. El tiroteo cesó cuando las víctimas cayeron fuera del automóvil.

Los agentes identificaron a los ocupantes del coche y trasladaron "urgentemente" al conductor y al copiloto al Hospital del Generalísimo, extremo que corrobora Sainz. Ingresaron a las 21:30. La autopsia de Batarrita, que llegó cadáver, desveló que tenía seis heridas de bala, dos de ellas en la cabeza. Así pues, no se trataba de más de cuarenta y nueve disparos, como decía haber contado EGI. "Como consecuencia de la lesión medular", Martín-Ballestero "presentaba desde el primer momento parálisis total de la mitad inferior del cuerpo". Ninguno de los disparos había sido hecho a quemarropa. Fernando Larizgoitia, sentado atrás, tuvo una fortuna extraordinaria: "resultó ileso en el tiroteo, si bien una bala atravesó el hombro izquierdo de su chaqueta". Se trataba de tres "personas de buena conducta y desde luego ajenos a toda actividad antisocial o subversiva", recalcaba la sentencia. El Peugot había recibido catorce impactos, produciéndole daños tasados en 8.025 pesetas (1.800 euros actuales).

José Sainz relata que, al enterarse de la tragedia, V.G.A., el primer denunciante, se desdijo "de cuanto había manifestado, aclarando que no pensó en la trascendencia de sus declaraciones". Confesó que "las hizo porque atravesaba una aguda crisis económica y pensaba pedir una certificación a la Policía de su buen comportamiento que pudiera ayudarle a resolverla. Nada de lo que había dicho era cierto”. ¿Pagó por su mentira? La única pista nos la da un artículo de Gudari de junio de 1961 en el que se anunciaba la detención en Vitoria de "un alto jefe de Falange, a quien se acusa de

\footnotetext{
${ }^{39}$ Ibídem, p. 125.
} 
haber hecho telefónicamente la falsa denuncia, para vengarse de la demanda que Batarrita había entablado contra él por unas 200.000 pesetas [44.500 euros actuales]" ${ }^{40}$. Sin embargo, entre los "altos jefes de Falange" de Vitoria no había nadie con esos apellidos. Ha sido imposible encontrar más datos sobre V.G.A., excepto que era natural de Toro (Zamora). Se trata de uno de los cabos sueltos del caso Batarrita. Otro, menor, es el papel del guardia jurado de la fábrica Inauto. Sainz se preguntaba en sus memorias si sus excompañeros de la Benemérita le habían informado de la denuncia de V.G.A. ¿Les había llamado al ver algo sospechoso "con la sana intención de colaborar"? Su respuesta a tal interrogante es que "la fatalidad había jugado una mala pasada" ${ }^{41}$.

Note bene: en ninguna de las casi mil doscientas páginas de la causa judicial se cita a ETA.

\section{El olvidado juicio del Tribunal Supremo (1965)}

La Audiencia de Bilbao absolvió a los diez agentes procesados porque era incapaz de asegurar cuál de todos ellos era el auténtico culpable. El Ministerio Fiscal no compartía dicha opinión: recurrió la sentencia ante el Tribunal Supremo, acusando únicamente al guardia civil I.G.M. Se le responsabilizaba de haber sido el primero en hacer fuego contra el automóvil, lo que había provocado la subsiguiente confusión y la tragedia. El nuevo juicio tuvo lugar en junio de 1965. Como informaron los diarios ${ }^{42}$, el Tribunal Supremo ratificó el veredicto de la Audiencia de Bilbao. La Sala argumentaba que "en la relación fáctica no figura de manera precisa quién fue el primero que disparó en la ocasión de autos" 43 .

El segundo juicio plantea nuevas incógnitas. La principal: el hecho de que se celebrara, teniendo en cuenta que todo parecía haberse cerrado en 1963. ¿Por qué el

\footnotetext{
${ }^{40}$ Gudari, ${ }^{\circ}$ 3, junio de 1961.

${ }^{41}$ José SAINZ GONZÁLEZ, Testimonios..., op. cit., p. 126.

42 El Correo Español y El Diario Vasco, 7 de julio de 1965.

43 Tribunal Supremo, Sala de lo Penal, Sección 1: "Sentencia (recurso de casación) n 1.218", 28 de junio de 1965 (recuperado de http://www.poderjudicial.es/search/indexAN.jsp). La documentación judicial generada en 1965 se añadió a la causa de 1963. Audiencia Provincial 1/3. AHPV.
} 
fiscal insistió en que se juzgara por segunda vez a I.G.M., prolongando durante un total de cuatro años y tres meses un proceso que podía tener derivaciones imprevistas? No tenemos ninguna certeza al respecto. Ahora bien, quizá no esté de más recordar que la familia de José Antonio Martín-Ballestero estaba muy bien situada en el régimen. Su suegro era el coronel de Aviación Luis Castañón de Mena, hermano de un general que acabaría dirigiendo el Ministerio del Ejército (1969-1973). Por otro lado, cuando en 1957 se casó la hermana de José Antonio, Marisol, actuó como juez el presidente del Tribunal Supremo y firmaron el acta como testigos de la novia el ministro y el subsecretario de Trabajo. El padre, Antonio Martín-Ballestero Costea, ejercía por aquel entonces de director de Jurisdicción del Trabajo. Antes había sido gobernador civil de Orense (1942-45) y La Coruña (1945-49) mientras que su hermano Luis, el tío de José Antonio, había sido instructor de la Causa General y gobernador civil de Logroño (1944-46) y Álava (1946-56). A principios de los años sesenta Antonio MartínBallestero impartía docencia como catedrático de Derecho Civil de la Universidad de Zaragoza, puesto que compaginaba con el procurador en las Cortes franquistas (19581964) y el de teniente fiscal de la Audiencia de dicha ciudad. En abril de 1964 fue nombrado fiscal jefe ${ }^{44}$.

Según las memorias de Sainz, en marzo de 1961 Antonio Martín-Ballestero había afirmado que su hijo "le había asegurado que quien había disparado contra él y a bocajarro, había sido un hombre vestido de uniforme con gorro y de poca estatura y que así se lo diría al Juez porque era la verdad". Los miembros de la Policía Secreta iban de paisano y los policías armados estaban demasiado lejos: el uniformado tenía que ser el guardia civil que detuvo el coche. Efectivamente, en el sumario podemos leer que, en una declaración efectuada cuando todavía estaba recuperándose en el hospital, José Antonio Martín-Ballestero había acusado a I.G.M. de haber sido el primero en disparar ${ }^{45}$.

En definitiva, su familia no solo tenía influencia, sino también un motivo creíble por el que perseguir judicialmente al guardia civil. Pero, entonces, ¿por qué había aceptado retirarse de la acusación particular en 1963? No lo sabemos. Tampoco si

\footnotetext{
${ }^{44}$ ABC, 6 de marzo 1946, 27 de noviembre de 1957, 31 de mayo de 1960 y 18 de abril de 1964.

45 José SAINZ GONZÁLEZ, Testimonios..., op. cit., p. 125.
} 
realmente los allegados de José Antonio Martín-Ballestero tuvieron algo que ver con el recurso presentado al Tribunal Supremo: es solo una sospecha y como tal hay que tomarla.

El otro enigma que envuelve este segundo juicio es por qué, a pesar de que había sido publicitado en la prensa de la época, no tardó en evaporarse de la historia: ningún autor lo ha citado nunca.

\section{De repente, un etarra. La inclusión de nuevos personajes en la trama (1963)}

En la primera parte de este trabajo hemos hecho un ejercicio de microhistoria para descubrir lo que ocurrió el 27 de marzo de 1961 y sus consecuencias jurídicas. En la segunda parte nos proponemos analizar cómo y por qué el nacionalismo vasco radical tergiversó e instrumentalizó la muerte de Javier Batarrita, dando finalmente lugar a la sesgada interpretación de Egaña Sevilla: que en Bolueta los agentes habían pretendido "fusilar" a Julen Madariaga y otros dos dirigentes de ETA. Se trata de una tesis insostenible. Tres hechos la refutan.

Por un lado, sabemos que la denuncia que puso en marcha la tragedia era falsa: los "terroristas" a los que se buscaba eran fruto de la imaginación de V.G.A., como él mismo terminó confesando. El testimonio del guardia jurado relacionó a estos personajes irreales con Batarrita y sus compañeros, convirtiéndolos en sospechosos. Al menos eso pensaron las autoridades policiales presentes en Vitoria, que ordenaron detener su coche a la entrada de Bilbao. Allí los agentes de las FOP esperaron, identificaron, pararon y dispararon a ese automóvil, del que no solo conocían el modelo, sino también la matrícula. Se trataba del Peugeot 203 de Batarrita. No de otro.

Por otro lado, como ha recordado el hijo de Javier Batarrita, "la supuesta confusión que hubiera podido haber entre la figura de mi padre y la de Julen Madariaga no se hizo pública, no se conocía en absoluto". Él decía haberse enterado "a través de algún libro que tocaba de forma tangencial aquel caso y en fechas recientes" ${ }^{\text {"6 }}$. $Y$ es que ninguna fuente coetánea mencionaba a ETA. La documentación localizada hasta

\footnotetext{
${ }^{46}$ Deia, 6 de abril de 2014. El testimonio de Javier Batarrita Gaztelu también está recogido en el documental ¿Por quién no doblan las campanas? (Maite Ibáñez, 2012).
} 
ahora revela que nadie vinculó a la organización con el "suceso de Bolueta" hasta abril de 1963. Es decir, dos años después de aquella fatídica noche. Se trató de un breve texto inserto en el boletín informativo de ETA, el Zutik Berriak, en el que se daba cuenta de la absolución de los diez agentes procesados. "Queremos denunciar desde estas columnas lo que realmente fue un asesinato premeditado, ya que hubo una equivocación de coche, pues sabemos que la intención era 'liquidar' a otras personas y precisamente de ETA". Zutik Berriak se basaba en una noticia publicada en la sección vasca del periódico francés Eclair-Pyrénées. Ahora bien, en tal diario se informaba de que las FOP habían tomado a Batarrita y sus compañeros por "terroristas", término que las autoridades y la prensa franquistas habían empleado en todo momento. No se nombraba a ETA ni a ninguno de sus militantes. Y es que Eclair-Pyrénées se estaba limitando a resumir las crónicas de los medios españoles, copiando incluso el error en la fecha, que Zutik Berriak reprodujo tal cual ${ }^{47}$. En definitiva, el intento de mezclar a ETA con el caso Batarrita llevó el sello de la propia ETA.

Por último, resulta difícil creer que el 27 de marzo de 1961 las FOP planearan una emboscada contra ETA, un colectivo al que nunca habían prestado la más mínima atención. En palabras de Patxo Unzueta, durante la primera mitad de los sesenta ETA no fue más que "un grupo propagandista con casi ilimitada fe en las virtualidades del papel impreso" ${ }^{\text {"48 }}$. La organización se centraba en el estudio y carecía tanto de la capacidad como de la decisión de emplear la violencia. Su primer ensayo tuvo lugar en el otoño de 1959, cuando colocaron pequeños explosivos de fabricación casera en el Gobierno Civil de Álava, una comisaría de Policía de Bilbao y el diario Alerta de Santander. ETA nunca reivindicó aquellos atentados, por lo que las autoridades se los atribuyeron a EGI, que en aquel momento estaban desplegando un gran activismo. Tal era así que las FOP, principalmente dedicadas a la persecución del Partido Comunista de España y sus satélites, se pusieron tras la pista de EGI, que sufrieron una gran caída entre finales de 1959 y principios de 1960. También fueron detenidos cuatro etarras que anteriormente habían pertenecido al organismo juvenil del PNV. Por

\footnotetext{
${ }^{47}$ Zutik Berriak, 5 de abril de 1963. Eclair-Pyrénées, 28 de marzo de 1963. La edición de este día me fue facilitada por los Archives départementales des Pyrénées-Atlantiques (Pau, Francia).

${ }^{48}$ José Luis UNZUETA, "La V Asamblea de ETA", Saioak, n 4 (1980), p. 3. Francisco LETAMENDIA, Historia del nacionalismo vasco y de ETA, San Sebastián, R\&B, 1994, vol. I, p. 259
} 
ejemplo, Julen Madariaga, quien achacaba su captura a la delación de sus antiguos correligionarios en EGI. La Policía, sostenía, "llegó a la conclusión de que existía otra organización, pero no supo el nombre. Pero el hecho es que alguno de nosotros desgraciadamente quedamos fichados, aunque no tuvimos juicio". Únicamente pasaron unos días en comisaría. A decir de Jon Nikolas, las FOP se limitaron a registrar los datos de los cuatro etarras sin relacionarnos con las nuevas siglas. Nada más. Según uno de los primeros integrantes del grupo, Juan José Etxabe, que hacía referencia a la etapa anterior a 1963, "todavía éramos desconocidos y la pertenencia no implicaba los peligros posteriores" ${ }^{\prime 4}$.

En realidad, las FOP no se interesaron por ETA hasta su primera acción confirmada y reivindicada, que tuvo lugar tres meses y medio después del "suceso de Bolueta". El 18 de julio de 1961 los militantes de la organización quemaron tres banderas rojigualdas en San Sebastián e intentaron hacer descarrilar un tren de veteranos requetés guipuzcoanos que acudían a dicha ciudad a conmemorar el $25^{\circ}$ aniversario de la sublevación franquista. A consecuencia de aquellos sabotajes se detuvo a una treintena de activistas y apareció el primer documento policial con referencias a ETA del que tenemos constancia. Significativamente, el texto, fechado el 11 de agosto de 1961, manejaba información averiada: apenas diferenciaba entre EGI y ETA y vinculaba a esta organización con el Partido Comunista de España ${ }^{50}$.

La actividad subversiva de ETA en Guipúzcoa no tuvo su réplica en Vizcaya. La Memoria de este Gobierno Civil certifica que 1961 se había caracterizado "por una recesión de todas las actividades de los elementos contrarios al Régimen". Se consignaba, eso sí, la captura de algunos individuos implicados en las acciones de Guipúzcoa, sin más detalles ${ }^{51}$. A decir de Jon Nikolas, al ser interrogado, uno de los etarras apresados describió físicamente a su responsable directo, del que sin embargo

\footnotetext{
${ }^{49}$ Gaizka FERNÁNDEZ SOLDEVILLA, "Otoño del 59. Los 'primeros pinitos' de ETA", Grand Place, no 8 , 2017 (en preparación). Gabriel CARRIÓN, ETA en los archivos secretos de la policía política de Franco, 1952-1969, Alicante, Agua Clara, 2002, p. 62. VVAA, Documentos Y, San Sebastián, Hordago, 1979, vol. I, pp. 31, 32 y 369. Punto y Hora, 18 al 24 de agosto de 1977. Garaia, 10 de marzo de 1977.

50 José SAINZ GONZÁLEZ, Testimonios..., op. cit., p. 142. Mikel AIZPURU, “¿El primer informe policial sobre ETA? Los archivos franquistas como fuente para la investigación histórica", Sancho el Sabio, ${ }^{\circ}$ 39, pp. 223-251. Zutik, 20 de noviembre de 1961. Zutik (Caracas), $n^{\circ} 13,1961$. VVAA, Documentos Y, op. cit., pp. 367-372.

51 "Memoria del Gobierno Civil de Vizcaya de 1961", 1962. AGCV.
} 
no sabía el nombre, reconociendo haberlo visto "en la Gran Vía de Bilbao en un coche modelo inglés". Esta declaración fue "clarificadora" para un responsable policial, "a quien le faltó tiempo para exclamar: ‘¡El cabrón de Madariaga!' y presentarse en Bakio donde efectuaron la detención de Julen". Era el 4 de agosto de 1961. A las FOP no les costó capturarlo porque tenían constancia de su paradero. $Y$ no se le consideraba un peligro para el régimen: Madariaga fue puesto en libertad provisional el 15 de enero de $1962^{52}$.

Tanto él como otros líderes de ETA aprovecharon la ocasión para huir al País Vasco francés, donde permanecerían hasta finales de 1964. Madariaga estaba allí cuando el periódico Eclair-Pyrénées dio la noticia de que diez agentes habían sido procesados por haber matado a Batarrita y herido a Martín-Ballestero al haberles confundido con "terroristas". También estaba allí cuando Zutik Berriak transformó a los "terroristas" en "etarras". ¿Tuvo algo que ver? ¿Entendió o entendieron mal? ¿Qué motivos tenían? ¿Se habían dado por aludidos, ya que, al fin y al cabo, ni Madariaga ni Federico Krutwig rehuían el término "terrorista"? ¿O se trató de una manipulación deliberada, de una utilización espuria de la muerte de Batarrita para dotar de un aura heroica a ETA? Para arrojar luz sobre tales interrogantes solo contamos con una carta que el propio Julen Madariaga escribió casi treinta años después.

\section{Clío atribulada. La rentabilidad del (maleable) pasado del País Vasco}

El caso Batarrita estuvo aparentemente enterrado durante más de dos décadas. En 1979 Jon Nikolas lo mencionó en el tomo inicial de Documentos $Y$, pero sin relacionarlo directamente con ETA. Sí dio ese paso en 1982 Gregorio Morán, quien introdujo en el relato el nombre de Julen Madariaga ${ }^{53}$. No cita cuál fue su fuente, pero a partir de entonces este y otros elementos erróneos se repetirían habitualmente en la prensa y en la bibliografía: el 26 de marzo de 1960 como fecha del "suceso", la

\footnotetext{
${ }^{52}$ Francisco LETAMENDIA, Historia..., op. cit., p. 259. Gabriel CARRIÓN, ETA en..., op. cit., p. 62. Antoni BATISTA, Madariaga. De las armas a la palabra, Barcelona, RBA, 2008, p. 102 y 104. VVAA, Documentos Y, op. cit., pp. 367-372.

53 VVAA, Documentos Y, op. cit., pp. 369. Gregorio Morán, Los españoles que dejaron de serlo, Barcelona, Planeta, 1982, p. 272.
} 
persecución a Madariaga, la confusión con su automóvil, la emboscada mortal de las FOP, los cuarenta y nueve impactos de bala, la amenaza policial que obligó a los etarras a armarse, la ausencia de indemnización, la omisión del juicio de 1965...

Algunos de estos yerros estaban en la cronología encontrada tras la detención de la cúpula de ETA en Bidart (País Vasco francés) en marzo de 1992. Al año siguiente un texto muy similar apareció en el primer volumen de Euskadi eta Askatasuna. Euskal Herria y la libertad (Txalaparta), la historia oficiosa de la banda terrorista, cuyo redactor principal fue Iñaki Egaña Sevilla. La obra incluye tres páginas acerca del "suceso de Bolueta", algunos de cuyos párrafos fueron reaprovechados para el reportaje de 2014. Euskadi eta Askatasuna conformó la versión definitiva del relato de la muerte de Batarrita. El libro enriquecía la trama que habían bosquejado Gudari y Zutik Berriak con nuevos detalles, como que había tenido lugar una pequeña reunión de etarras en Vitoria o el hecho de que Madariaga estuviese estudiando en Cambridge en esas fechas. No cita su fuente, pero casi todos aquellos datos coinciden con los que aporta una carta de Madariaga, fechada el 16 de mayo de 1991. No obstante, también se detectan una crucial diferencia entre la versión de Madariaga y la historia oficiosa de ETA. Madariaga recordaba que el "problema" nunca se había aclarado del todo, pero aventuraba una presunción, la de la confusión de las víctimas con etarras, apoyándose en dos indicios. Uno, que poseía un Peugeot 203 igual al de "Baztarrika [sic]" y que en Vizcaya había pocos coches de tales características. Dos, la ya mencionada reunión de Vitoria. La "hipótesis" de Madariaga era que los policías podrían haber estado siguiendo la pista de Benito del Valle o de él mismo, y que quizá sospecharon que algunos miembros de ETA, entre ellos el propio Madariaga, iban a realizar un viaje. Todo eso sería válido, matizaba, si "el enemigo" no había visto ni el coche ni a sus tres ocupantes. Se trataba, y lo reconocía en todo momento, de una mera conjetura. Ahora bien, el autor del citado fragmento de Euskadi eta Askatasuna no se refería a suposiciones, sino a certidumbres. Si es que se basó en la carta, convirtió en real lo que Madariaga solo planteaba como una posibilidad. La misiva, por cierto, está colgada en la web de Euskal Memoria Fundazioa, organismo presidido por Egaña Sevilla. Se trata de uno de los pilares del revisionismo patrocinado por la "izquierda abertzale". Según la página web de la fundación, "la memoria histórica en Euskal Herria no se inscribe en el plano de la discusión entre eruditos. Es el 
mecanismo más eficaz para preservar que el testigo de la verdad y de la resistencia pase a las siguientes generaciones" ${ }^{24}$.

Siguiendo el guion que la obra Euskadi eta Askatasuna había establecido, otros autores cercanos al nacionalismo radical empezaron a hacer alusiones puntuales al caso Batarrita. Se trata, por lo general, de proselitistas sin formación especializada, que no solo desprecian la historia como disciplina académica, sino que, además, escriben una literatura militante, ad probandum, con nulo respeto por el método y la deontología del historiador. Por ejemplo, Iker Casanova, quien explicaba así el "suceso de Bolueta": "el nacimiento de ETA y su fuerte activismo encienden las luces rojas [de Ios policías] y deciden atajar el problema de una forma expeditiva y ejemplarizante". ¿A qué "fuerte activismo" se refería? No se sabe. ¿Con qué pruebas? No hacían falta: su trabajo no persigue el avance del conocimiento científico, sino de una causa política. No obstante, a pesar de su escasa calidad y su evidente propósito publicitario, estos libros tienen una notable difusión ${ }^{55}$.

Como ya se ha dicho, en 2010 Iñaki Egaña Sevilla publicó un artículo en el que sostenía que Batarrita y Martín-Ballestero pertenecían "a conocidas familias franquistas". En esto no hacía más que seguir la estela tanto de Euzko Deya como de la carta de Madariaga, que identificaba a Batarrita y Martín-Ballestero como probablemente derechistas, lo que ha reiterado en sus memorias. Sin embargo, Egaña Sevilla hizo desaparecer aquella adscripción ideológica de todos sus textos posteriores. Ya no constaba. Irónicamente, aquel artículo de 2010 quería denunciar el "gran memoricidio" que "sufre nuestra sociedad". "Lo dijo Joseph Goebbels ministro de Propaganda de la Alemania de Hitler: 'una mentira repetida mil veces se convierte en verdad"' 56 .

\footnotetext{
${ }^{54}$ La cronología de ETA en www.matrix666.net/wp-content/musica/1024.pdf Luis NUÑEZ (coord.), Euskadi eta Askatasuna. Euskal Herria y la libertad, Tafalla, Txalaparta, 1993, vol. I, pp. 54-56. La carta de Madariaga se encuentra en http://www.euskalmemoria.eus/es/db

${ }^{55}$ Ángel REKALDE GOIKOETXEA, Mugalaris. Memorias del Bidasoa, Tafalla, Txalaparta, 1997, pp. 2728. José Luis ÁLVAREZ ENPARANTZA, Euskal Herria en el horizonte, Tafalla, Txalaparta, 1997, p. 191. Rui PEREIRA, La guerra desconocida de los vascos, Tafalla, Txalaparta. 2001, p. 72. José María PEREZ BUSTERO, Los nuevos vascones, Tafalla, Txalaparta, 2007, p. 63. Iker CASANOVA, ETA 19582008, Tafalla, Txalaparta, 2007, pp. 30-31. Joxean AGIRRE (coord.), No les bastó Gernika. Euskal Herria 1960-2010, Andoain, Euskal Memoria Fundazioa, 2010, pp. 289-290.

${ }^{56}$ Iñaki EGAÑA SEVILLA, "Memoricidio", op. cit. Fue reproducido en Iñaki EGAÑA y Giovanni GIACOPUZZI, La construcción del enemigo: ETA a la vista de España, 2010-2012, Tafalla, Txalaparta,
} 
De cualquier manera, apenas se le concedía importancia y espacio al caso Batarrita. Esa tendencia no se invirtió hasta el 2011, tras el anuncio del "cese definitivo" del terrorismo. En tal crítica coyuntura para el nacionalismo vasco radical, el entorno intelectual de ETA se volcó en apuntalar su legitimidad histórica: el control del pasado era crucial para perseverar en el presente. Ya el 2 de octubre un editorial de Gara había avisado "a los que quieren un relato de vencedores y vencidos" de que "en Euskal Herria vencerá quien convenza, primero a los suyos y luego al resto. Los dirigentes independentistas ya han logrado lo primero y han hecho grandes avances en lo segundo. Los unionistas, ni lo uno ni lo otro". Al año siguiente José Mari Esparza, director de la editorial Txalaparta, deseaba "que la izquierda abertzale se nutra de su abnegado pasado, lo cultive en sus nuevos militantes y lo sepa trasmitir, con humildad, a Bildu y al resto de la sociedad vasca. Porque ganada la batalla de la Memoria, habremos ganado todas. $Y$ todos" 57 .

Y el caso Batarrita confería una gran baza en tal "batalla". A partir del año 2000 se había responsabilizado a ETA de la bomba que acabó con la vida de Begoña $\mathrm{Urroz}^{58}$, supuesto que de alguna manera fue oficializado cuando en 2010 el Congreso de los Diputados instituyó el Día en homenaje a las Víctimas del Terrorismo en la fecha del atentado. Urroz era vista como el pecado original de la banda: que su acción inaugural fuera el asesinato de un bebé implicaba que la historia de ETA estaba irremediablemente deslegitimada desde el principio. Era moralmente indefendible incluso desde la perspectiva del nacionalismo vasco radical. Sin embargo, como no tardó en comprobarse, tal atribución era un error: el atentado había sido obra del DRIL $^{59}$. La primera víctima mortal de ETA no fue Begoña Urroz, sino el guardia civil José Antonio Pardines, asesinado el 7 de junio de 1968. Aquel cambio creó una ventana de oportunidad para la propaganda abertzale. La muerte de Javier Batarrita dejó de ser una anécdota histórica para transformarse en un arma de choque para la "batalla de la Memoria". Y como tal fue utilizada: la "primera víctima" la había

2012, pp. 31-32. Antoni BATISTA, Madariaga..., op. cit., p. 95. Julen MADARIAGA, Egiari zor, San Sebastián, Erein, 2014, p. 81.

${ }^{57}$ Gara, 2 de octubre de 2011. José Mari ESPARZA, "El Sortu que yo quisiera”, Gara, 12 de julio de 2012.

${ }^{58}$ Ernest LLUCH, "La primera víctima de ETA”, El Correo, 19 de septiembre de 2000.

${ }^{59}$ Santiago de PABLO, “¿La primera víctima de ETA?”, El Correo, 19 de junio de 2010. 
provocado el "Estado", por lo que la violencia de ETA únicamente debía verse como legítima defensa ante un ataque previo. A partir de ahí, la tergiversación del "suceso de Bolueta" servía para justificar la historia criminal de la banda. En palabras de Egaña Sevilla, "mal empezamos en la cuestión de las víctimas del conflicto cuando las reducimos sólo a las ocasionadas por ETA desde 1968. ETA es una expresión del conflicto y no su origen". Y sacaba a colación que "Batarrita tenía, y el recuento es de la misma prensa franquista, 49 balazos a quemarropa. Un fusilamiento en toda regla". Se trataba de otr mentira, pero, siguiendo la máxima de Goebbels citada por Egaña, ha sido repetida una y otra vez. Por ejemplo, en libros como La guerra no declarada. Terrorismo de Estado en Euskal Herria, que sentenciaba: "Tirar a matar: todo empezó en Bolueta"60.

Los intelectuales orgánicos del nacionalismo radical no han sido los únicos en manipular el caso Batarrita. En abril de 2011 el veterano político del PNV Iñaki Anasagasti publicó una entrada en su blog en la que también inventaba detalles. Por citar tres: que "la prensa solamente se pudo hacer eco, en la página 13 y en la sección de Deportes de una breve nota"; que la absolución de 1963 se debió a la aplicación de la "eximente completa de responsabilidad motivada por actos fundados en 'la obediencia debida"; o que "los policías fueron trasladados de Bilbao, con aumento de sueldo y escala". Batarrita "fue asesinado porque le confundieron con un algo naciente en aquel año sesenta y uno. Y nadie les ha pedido perdón". La conclusión política era que "la transición española ha sido un fraude. Y la ley de amnistía de 1977 una ley de punto y final (....). Aquí Franco lo dejó todo 'atado y bien atado"”61.

Resulta significativo, además, que Anasagasti aseverara que "Batarrita era nieto de un concejal nacionalista del PNV en tiempos de la República", cuando solo en una ocasión Gudari lo había identificado como "hijo". Un Antonio Batarrita Macoaga se presentó en las listas del PNV a las elecciones municipales de 1931, pero no salió

\footnotetext{
60 Iñaki EGAÑA SEVILLA, “¿Son iguales todas las víctimas?”, Gara, 30 de octubre de 2011, “Javier Batarrita, la primera víctima”, Gara, 27 de marzo de 2014, "ETA, medio siglo en la centralidad política”, Gara, 22 de octubre de 2011. Juan Maria ZULAIKA, "Primero fue Franco", Gara, 23 de junio de 2016. Joxean AGIRRE et alii, La guerra no declarada. Terrorismo de Estado en Euskal Herria, Andoain, Euskal Memoria Fundazioa, 2014, p. 471. Ricardo ZABALZA, ETA. Una historia en imágenes, 1951-1978, Tafalla, Txalaparta, 2015, p. 43.

${ }^{61}$ Recuperado de http://blogs.deia.com/anasagasti/tag/javier-batarrita/
} 
elegido. Desconocemos si tenía algún tipo de parentesco con la víctima. En cambio, sí sabemos que Javier Batarrita Elexpuru tenía de nacionalista vasco lo mismo que de franquista: poco o nada. Lo dejó escrito su querido amigo ("lagun maitea"), el poeta Gabriel Aresti: "bizikleteroa, denon adiskidea,/ ideolojietan etzen inoiz sartu./ Bakean bizi zen mundu guztiarekin" (ciclista, amigo de todos,/ nunca se metió en ideologías./ Vivía en paz con todo el mundo) ${ }^{62}$.

En abril de 2014 Deia publicó un reportaje de Enrique Santarén: "Batarrita, 49 tiros en una ejecución policial 'por error'". Se inspiraba tanto en Anasagasti como en Gudari, "única [publicación] que dio una versión real de lo ocurrido". El objetivo de las FOP era "cazar -literalmente- a Julen Madariaga, uno de los fundadores de la activa organización. Hubiese sido un gran éxito, un regalo para el nuevo gobernador civil, Antonio Ibáñez Freire, que llevaba solo veinte días en el cargo. Serían héroes". Por añadidura, la Audiencia de Bilbao absolvió a "todos los imputados por algo similar a la obediencia debida. En cualquier caso, es imposible contrastarlo ya que alguien se encargó, oportunamente, de hacer desaparecer el sumario y cualquier expediente del procedimiento" ${ }^{\prime 3}$.

Se equivocaba. Las fuentes sobre el caso Batarrita siempre han estado disponibles en los archivos, las hemerotecas e internet. Sencillamente nadie se había molestado en buscarlas.

\section{Conclusiones}

Se ha hecho frecuente escuchar en el País Vasco que se está librando una "batalla por la memoria" o "batalla de relatos". Sin embargo, la existencia de relatos contrapuestos no significa que estos tengan el mismo valor. Inventar y manipular no es equiparable al trabajo de biblioteca, hemeroteca y archivo: el relato del propagandista no es el mismo que el del historiador. La prioridad absoluta del primero es servir a su causa política, aunque el precio sea forzar la historia: la nobleza del fin justifica los medios. El segundo intenta explicar el pasado de una forma veraz y rigurosa, para lo

\footnotetext{
62 Recuperado de http://www.argia.eus/albistea/ez-urroz-ez-pardines-javier-batarrita-izan-zengatazkaren-lehen-hildakoa Jon JUARISTI, Cambio de destino, op. cit., p. 99.

${ }^{63}$ Deia, 6 de abril de 2014.
} 
que se vale de la metodología propia de su oficio. El historiador aspira a acercarse lo máximo posible a la verdad, independientemente de lo incómoda que sea. $Y$ a veces lo es.

El examen de las fuentes desvela que la muerte de Javier Batarrita y las heridas de José Antonio Martín-Ballestero fueron el sangriento desenlace de una serie encadenada de mentiras, negligencias, errores y malentendidos. La responsabilidad de la tragedia recae en el empresario arruinado que realizó la falsa denuncia, el guardia jurado que marcó como sospechosos a tres hombres inocentes, los mandos policiales que desde Vitoria no transmitieron correctamente los datos, los que se encontraban en Bilbao y fueron incapaces de organizar un control efectivo, el agente que hizo el disparo inicial sin ningún motivo y sus compañeros, que respondieron a tiros a un ataque imaginario. Como sentenció la Audiencia de Bilbao, uno de los diez encausados debió haber sido declarado culpable del "delito de imprudencia temeraria con resultado de homicidio, lesiones graves y daños": el policía o guardia civil que abrió fuego. Pese a los indicios que apuntan a I.G.M., no podemos asegurar que se tratara de él. De todos los cabos sueltos que quedan, este es el más importante.

En noviembre de 2012 la Comisión de Valoración de Sufrimientos Injustos del Gobierno vasco reconoció a Batarrita como "víctima de violación de derechos humanos producida en el contexto de la violencia de motivación política vivida en la Comunidad Autónoma del País Vasco", por lo que se le concedió a la familia una indemnización de 135.000 euros. Desde luego, no hay nada que objetar en ese sentido: fue víctima del franquismo. Ahora bien, sí lo hay en lo que respecta a algunas de las otras conclusiones de la Comisión. Grosso modo, se dio por válido el relato de la "izquierda abertzale" sin contrastarlo primero: el dictamen únicamente se había basado en el testimonio del hijo y la viuda de Batarrita, una noticia aparecida en $A B C$ y el Gudari de abril de $1961^{64}$. En 2014 la Secretaría General para la Paz y la Convivencia del Gobierno vasco editó los polémicos Retratos municipales de las vulneraciones del derecho a la vida en el caso vasco. El de Bilbao incluía a Javier Batarrita Elespuru [sic], reproduciendo los mismos yerros que el acuerdo de la Comisión ${ }^{65}$. Es una muestra de

\footnotetext{
64 “Dictamen de la Comisión de Valoración", Vitoria, 19 de noviembre de 2012.

${ }^{65}$ SIN AUTOR, Retratos municipales de las vulneraciones del derecho a la vida en el caso vasco. Bilbao,
} 
cómo las políticas de la memoria que no se sustentan en la historia académica ponen en peligro sus encomiables propósitos. Para evitarlo, las instituciones deben respetar la labor de los profesionales, quienes, a su vez, han de potenciar su papel mediante la divulgación de sus descubrimientos. Por ejemplo, la aparición de un adelanto del presente artículo en la prensa obligó a la Comisión de Valoración del Gobierno vasco a corregir su versión del caso, plasmando en su informe definitivo una más ajustada a los hechos $^{66}$.

Javier Batarrita no solo fue víctima del franquismo, sino también de la falsedad deliberada. ETA no tuvo nada que ver con lo ocurrido el 27 de marzo de 1961 a la entrada de Bilbao. La víctima no recibió cuarenta y nueve impactos de bala. Los agentes que le dispararon no se confundieron de coche: su objetivo era el Peugeot 203, matrícula M-94.430, de Batarrita. No hay ninguna prueba de que las autoridades ordenasen la ejecución extrajudicial de unos "terroristas" y menos de Julen Madariaga, al que las FOP habían tenido en el calabozo en 1960 y al que volverían a tener a su merced en agosto de 1961. Ni siquiera hay un documento policial anterior a esa fecha que demuestre que la dictadura conociera la existencia de ETA. Como poco, no le preocupó hasta que realizó su primera acción el 18 de julio de 1961. Y no antes.

Estas mentiras están al servicio de un proyecto político: el del nacionalismo vasco radical. Egaña Sevilla ha presentado a Batarrita como "la primera víctima del llamado conflicto vasco, en su fase más reciente", expresión análoga a la que ha utilizado en una obra posterior: "la primera víctima mortal del moderno conflicto vasco" 67 . El "conflicto" es la forma con la que la "izquierda abertzale" denomina a su narrativa histórica: una contienda étnica en la que los invasores españoles y los invadidos vascos llevarían enzarzados desde hace centurias (o incluso milenios). Con el fin de que puedan encajar en tal tesis, el revisionismo abertzale ha reelaborado diferentes episodios históricos que son presentados como eslabones de una misma cadena o, por decirlo de otro modo, partes de un gran ciclo narrativo cuyo mínimo

1960-2010, Gobierno vasco, 2014, p. 96.

${ }^{66}$ Gaizka FERNÁNDEZ SOLDEVILLA, "La verdad sobre el caso Batarrita", El Correo, 28 de febrero de 2017. VVAA, Saliendo del olvido. Informe de la Comisión de Valoración sobre víctimas de violaciones de derechos humanos y otros sufrimientos injustos producidos en un contexto de violencia de motivación política en la Comunidad Autónoma del País Vasco 1960-1978, Vitoria, Gobierno vasco, 2017.

${ }^{67}$ Ricardo ZABALZA, ETA..., op. cit., p. 43. 
común denominador es la agresión foránea: desde la derrota franca en Roncesvalles (778) a ETA, pasando por las guerras carlistas del siglo XIX y la civil del $X X^{68}$.

La de la "izquierda abertzale" no ha sido una guerra real, sino una "guerra imaginaria", como acertadamente la bautizó Antonio Elorza ${ }^{69}$. Ahora bien, fijar y difundir este relato resulta una tarea crucial para la supervivencia del nacionalismo radical tal y como se entiende a sí mismo: como un movimiento heredero de ETA. Y es que el "conflicto" dota de un sentido trascendental a todo lo que hicieron los terroristas y quienes les aplaudieron. Sirve para legitimar aquello que, de otro modo, serían simples crímenes.

Reescribiendo el pasado, la "izquierda abertzale" publicita la imagen de una guerra provocada por una invasión extranjera, la del "Estado", el auténtico culpable del ciclo de violencia que ha asolado el País Vasco y Navarra. En ese sentido, el caso Batarrita es un ejemplo paradigmático de alteración e instrumentalización de la historia. La presentación de su muerte como la ejecución extrajudicial planeada contra tres líderes de ETA ha sido utilizada para explicar por qué la propia organización empezó a asesinar en 1968 y no paró hasta 2011 , causando 845 víctimas mortales ${ }^{70}$. Al fin y al cabo, la banda no hacía sino actuar en legítima defensa contra la violencia previa, foránea y desproporcionada del "Estado". Desde tal perspectiva, todo comenzó cuando, con el objetivo de acabar con Madariaga, las FOP habían matado a Javier Batarrita, "la primera víctima del conflicto".

Pero no, no fue Batarrita. Parafraseando a Hiram Johnson, la primera víctima del "conflicto" fue la verdad.

\footnotetext{
${ }^{68}$ Gaizka FERNÁNDEZ SOLDEVILLA, La voluntad del gudari. Génesis y metástasis de la violencia de ETA, Madrid, Tecnos, 2016, pp. 23-61. PÉREZ PÉREZ, José Antonio y LÓPEZ ROMO, Raúl, "La memoria histórica del Franquismo y la Transición. Un eterno presente", en MOLINA, Fernando y PÉREZ PÉREZ, José Antonio (eds.), El peso de la identidad. Mitos y ritos en la historia vasca, Marcial Pons, Madrid, 2015, pp. 226-263. RIVERA, Antonio, "Cuando la mala historia es peor que la desmemoria (acerca de los mitos de la Historia contemporánea vasca)", El valor de la palabra, $n^{\circ} 4$ (2004), pp. 41-72.

69 Antonio ELORZA, La religión política. "El nacionalismo sabiniano" y otros ensayos sobre nacionalismo e integrismo, San Sebastián, R\&B, 1995, p. 49.

${ }^{70}$ Raúl LÓPEZ ROMO, Informe Foronda: los efectos del terrorismo en la sociedad vasca (1968-2010), Madrid, Los Libros de la Catarata, 2015.
} 